\title{
Assessment on Energy Self-Sufficiency Rate for Building Integrated Photovoltaics and Fuel Cell System in Japan
}

\author{
Akira Nishimura1, Satoshi Kitagawa1, Masafumi Hirota1, Eric $\mathrm{Hu}^{2}$ \\ ${ }^{1}$ Division of Mechanical Engineering, Graduate School of Engineering, Mie University, Tsu, Japan \\ ${ }^{2}$ School of Mechanical Engineering, The University of Adelaide, Adelaide, Australia \\ Email: nisimura@mach.mie-u.ac.jp
}

How to cite this paper: Nishimura, A., Kitagawa, S., Hirota, M. and Hu, E. (2017) Assessment on Energy Self-Sufficiency Rate for Building Integrated Photovoltaics and Fuel Cell System in Japan. Smart Grid and Renewable Energy, 8, 195-211. https://doi.org/10.4236/sgre.2017.86013

Received: May 12, 2017

Accepted: June 24, 2017

Published: June 27, 2017

Copyright (๑) 2017 by authors and Scientific Research Publishing Inc. This work is licensed under the Creative Commons Attribution International License (CC BY 4.0).

http://creativecommons.org/licenses/by/4.0/

\begin{abstract}
A building integrated photovoltaic (PV) and fuel cell (FC) system is proposed for assessment of the energy self-sufficiency rate in a city in Japan. The electricity consumed in the building is mainly supplied by solar panels, while the gap between the energy demand and supply is solved by the FC that is powered by the $\mathrm{H}_{2}$ produced by water electrolysis with surplus power of PV. A desktop case study of using the proposed system in Tsu city which is located in central part of Japan, has been conducted. The results found that the self-sufficiency rates of $\mathrm{PV}$ system to electricity demand of households $\left(R_{\mathrm{PV}}\right)$ during the daytime in April and July are higher than those in January and October. The results also reveal that the self-sufficiency rate of FC system to the electricity demand $\left(R_{\mathrm{FC}}\right)$ is $15 \%-38 \%$ for the day when the mean amount of horizontal solar radiation is obtained in January, April, July and October. In addition, it is found the optimum tilt angle of solar panel installed on the roof of the buildings should be 0 degree, i.e., placed horizontally.
\end{abstract}

\section{Keywords}

Smart Building, Photovoltaics, $\mathrm{H}_{2}$ Produced by Water Electrolysis, Fuel Cell, Self-Sufficiency Rate

\section{Introduction}

Fossil fuel reserves are limited and intensive burning of hydro-carbon based fuel sources are impacting on global climate. There is continuous encouragement to increase the penetration of environmental friendly energy sources for fulfilling growing energy demand and also to minimize the use of hydro-carbon based power plants. Renewable energy sources such as wind, solar photovoltaic (PV), 
solar thermal, geothermal, bio-energy are drawing attention as alternative environment friendly energy sources. However, the energy density of these renewable energy sources is low. Most of them are dependent on nature and have intermittent characteristics. Therefore, it is very important to develop proper strategies and technologies to integrate these renewable energy sources into the power system network in order to fulfill the energy demand.

Integrating renewable energy sources into the existing energy system network is an effective approach in the development of the so-called smart cities. Introducing renewable energy systems into the built environment (i.e. building) is a typical such approach. However, in the built environment, it is challenging to integrate intelligently renewable energy sources and distributed generators as the existing building infrastructures are not designed to accept them into the power system infrastructure. The development of a smart city or a smart building requires harmonizing the renewable energy system with existing heat and power system infrastructure, and with new monitoring and control system [1].

Integrating renewable energy on the building has been investigated recently well. Many researches on building integrated that wind turbine has been conducted recently [2]-[7]. Some researches on building integrated solar thermal system have been also reported [8] [9] [10]. In addition, the research on building integrated ground heat pump has been investigated [11]. Furthermore, the hybrid building systems such as PV and wind turbine [12]-[17], PV and solar thermal systems [18]-[25], and PV and geothermal heat pump [26] have been studied well.

Integrating/installing solar panels on the roof and/or side wall of the buildings is a typical way to make the building energy self-sufficient. Such kind of building integrated that PV systems (BIPV) have been studied by many researchers [27]-[37]. According to some review papers [27] [28], BIPV installation is increasing every year and PV systems are integrated into different parts of the building such as roof, external building wall, façade, and windows, although the majority of installations is on roof-top [29]. Most of the researches on BIPV focused on economic and environmental assessment evaluating by investment recovery with consideration of power generation performance [30] [31], life cycle cost (LCC) [22] [32] and energy payback time (EPBT) [27] [33]. In addition, some studies investigated the effect of thermal management of PV module on the power generation performance of BIPV [21] [34]. Although the power generation performance of BIPV was investigated under several conditions of PV module orientation in some case studies [27] [35] [36], the optimum tilt angle of PV module installation on the roof of the building, which is believed to be very important to obtain the high power generation performance of BIPV, was not clarified well.

Due to solar energy's intermittent nature, the BIPV system normally requires a sort of energy storage system or grid-connected mechanism. The typical energy storage system in associated with normal PV systems such as battery bank and hydrogen produced by water electrolysis produced by the power of PV sys- 
tem are well known and these combination systems have been studied numerically as well as experimentally [37]-[47]. However, the research on BIPV and energy storage system is lack, although the ice storage system combined with BIPV was proposed [48]. In addition, there are some studies on the energy demand coverage performance of grid-connected BIPV without energy storage system [30] [31].

In this paper, a desktop case study has been conducted on a proposed BIPV system. The proposed BIPV system consists of solar panels and fuel cell (FC). The $\mathrm{H}_{2}$ required by the $\mathrm{FC}$ are provided from the water electrolyzer with surplus power of PV. The FC would therefore be able to solve (partly) the gap between the electricity demand (by the building) and supply capacity of the PV panel due to the intermittent power generation of the PV system. As the PV panels were assumed to be installed on the roof of the building, the solar panel setting procedure is also investigated in this paper in order to clarify the maximum power could be generated from the BIPV. Compared the electricity demand data of household in Japan [49], the optimum power supply way to cover the electricity demand has been investigated. In addition, the self-sufficiency rate of power supply of the proposed BIPV system to electricity demand has been estimated in the case study.

\section{Case Study}

\subsection{Estimation of Power Generation from the PV System}

The building model used in the case study is $10 \mathrm{~m}$ width, $40 \mathrm{~m}$ length and $40 \mathrm{~m}$ height ( $=10$ stories) [50]. It was assumed that 40 households lived in the building described in the reference [51]. The BIPV system assumed to be installed on the top of the building consists of solar panels and a FC using $\mathrm{H}_{2}$ produced by water electrolysis with surplus power of PV.

The power generated by PV system is calculated by using the following equation [52]:

$$
E_{P V}=H \times K \times P / 1
$$

where $E_{P V}$ is hourly electric power of PV system $(\mathrm{kWh}), H$ is amount of solar radiation $\left(\mathrm{kWh} / \mathrm{m}^{2}\right), K$ is power generation loss factor $(-), P$ is system capacity of PV $(\mathrm{kW}), 1$ is solar radiation under standard state (AM1.5, solar radiation: 1 $\mathrm{kWh} / \mathrm{m}^{2}$, module temperature: 25 degree Celsius) $\left(\mathrm{kW} / \mathrm{m}^{2}\right)$.

In this study, the high performance PV P250a Plus produced by Panasonic whose module conversion efficiency and maximum power per module are 19.5\% and $250 \mathrm{~W}$ [53], respectively is adopted for PV system. The size of PV module is $1580 \mathrm{~mm} \times 812 \mathrm{~mm} \times 35 \mathrm{~mm} . P$ is calculated by installing this PV module on a roof of the building model, which is $75 \mathrm{~kW}_{p}$ (=300 solar panels). $K$ is calculated by using the following equation:

$$
K=K_{p} \times K_{m} \times K_{i}
$$

where $K_{p}$ is power conversion efficiency of power conditioner $(-), K_{m}$ is correction factor decided by module temperature $(-), K_{i}$ is power generation loss by 
interconnecting and dirty of module surface (-). In this study, $K_{p}$ and $K_{i}$ are set at 0.945 and 0.95 , respectively. $K_{p}$ is assumed by referring to the performance of commercial power conditioning device VBPC259B3 manufactured by Panasonic [54]. $K_{m}$ is calculated by the following equation:

$$
K_{m}=1-\frac{\left(T_{m}-T_{s}\right) C}{100}
$$

where $T_{m}$ is $\mathrm{PV}$ module temperature (degree Celsius), $T_{s}$ is temperature under standard test condition ( $=25$ degree Celsius), $\mathrm{C}$ is temperature correction factor which is 0.35 [55] (\%/degree Celsius). $T_{m}$ is calculated by using the following equation [56]:

$$
T_{m}=T_{a}+\left(\frac{46}{0.41 U_{m}^{0.8}+2}\right) H-2
$$

where $T_{a}$ is ambient air temperature (degree Celsius), $U_{m}$ is wind velocity over module of $\mathrm{PV}(\mathrm{m} / \mathrm{s})$.

The meteorological data, such as solar radiation, the ambient air temperature, and wind velocity of some cities in Japan are from the data base METPV-11 during the period from 1999 to 2009 [57] and the irradiation data of the project "PV300" during the period from August, 2012 to July, 2014 [58]. An example of meteorological data of METPV-11 for Tsu in Japan is shown in Figure 1. In this figure, a red circle, a green triangle and a flag symbol indicate the amount of horizontal solar radiation, the air temperature and a wind speed including direction, respectively. The solar radiation data for several tilt angles can be obtained from METPV-11 by changing configuration. Table 1 also lists an example data of PV300, which shows the data of air temperature and amount of horizontal solar radiation at $10 \mathrm{sec}$ intervals on $1^{\text {st }}$ August, 2013 for Tsu in Japan.

It is important to consider the impact of shadow on power generation performance when PV system is installed. The longest shadow length which is obtained at AM 9:00 on the winter solstice is calculated by the following equation [52]:

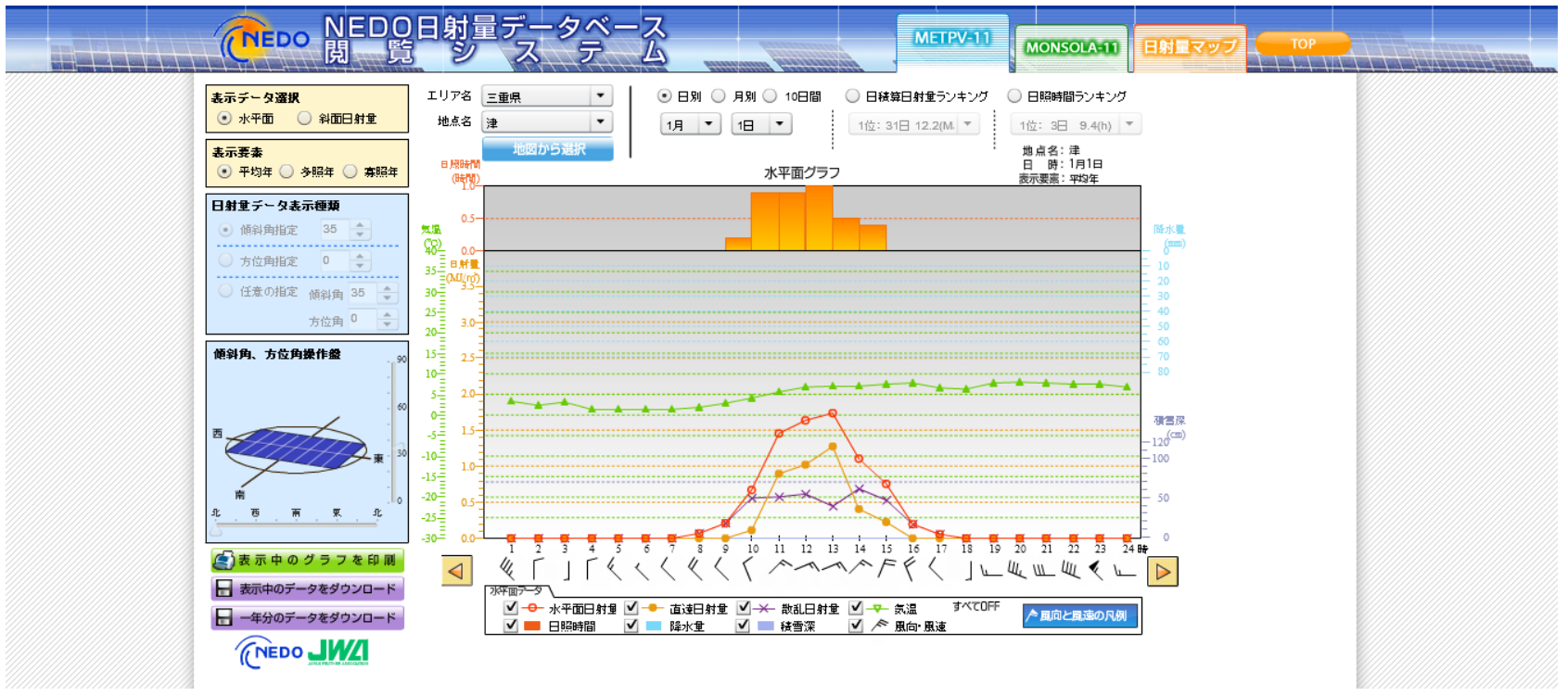

Figure 1. Example of meteorological data of METPV-11 (Tsu, Japan). 
Table 1. Example data of PV300 on $1^{\text {st }}$ August, 2013 for Tsu in Japan.

\begin{tabular}{|c|c|c|c|c|c|c|c|}
\hline Year & Month & Day & Hour & Min & $\mathrm{Sec}$ & $\begin{array}{c}\text { Amount of horizontal } \\
\text { solar radiation }\left(\mathrm{kW} / \mathrm{m}^{2}\right)\end{array}$ & $\begin{array}{l}\text { Air temperature } \\
\text { (degree Celsius) }\end{array}$ \\
\hline 2013 & 8 & 1 & 9 & 0 & 0 & 0.1179 & 30.7 \\
\hline 2013 & 8 & 1 & 9 & 0 & 10 & 0.1158 & 30.8 \\
\hline 2013 & 8 & 1 & 9 & 0 & 20 & 0.1115 & 30.7 \\
\hline 2013 & 8 & 1 & 9 & 0 & 30 & 0.1130 & 30.8 \\
\hline 2013 & 8 & 1 & 9 & 0 & 40 & 0.1150 & 31.0 \\
\hline 2013 & 8 & 1 & 9 & 0 & 50 & 0.1120 & 30.9 \\
\hline 2013 & 8 & 1 & 9 & 1 & 0 & 0.1107 & 30.8 \\
\hline 2013 & 8 & 1 & 9 & 1 & 10 & 0.1123 & 30.8 \\
\hline 2013 & 8 & 1 & 9 & 1 & 20 & 0.1166 & 31.0 \\
\hline 2013 & 8 & 1 & 9 & 1 & 30 & 0.1179 & 30.9 \\
\hline 2013 & 8 & 1 & 9 & 1 & 40 & 0.1183 & 30.8 \\
\hline 2013 & 8 & 1 & 9 & 1 & 50 & 0.1194 & 30.8 \\
\hline 2013 & 8 & 1 & 9 & 2 & 0 & 0.1229 & 30.8 \\
\hline 2013 & 8 & 1 & 9 & 2 & 10 & 0.1249 & 30.6 \\
\hline 2013 & 8 & 1 & 9 & 2 & 20 & 0.1267 & 30.5 \\
\hline 2013 & 8 & 1 & 9 & 2 & 30 & 0.1270 & 30.3 \\
\hline 2013 & 8 & 1 & 9 & 2 & 40 & 0.1262 & 30.1 \\
\hline 2013 & 8 & 1 & 9 & 2 & 50 & 0.1258 & 30.1 \\
\hline 2013 & 8 & 1 & 9 & 3 & 0 & 0.1298 & 30.4 \\
\hline
\end{tabular}

$$
L=\frac{1}{\tan \alpha} \times \cos \beta \times h
$$

where $L$ is the longest shadow length of solar panel to north direction (mm), $\alpha$ is solar altitude (degree), $\beta$ is solar azimuth angle from north and south direction (degree), $h$ is height of solar panel (mm).

In other words, the solar panels need to keep $L$ distance apart in N-S direction to avoid the shadowing each other. The number of solar panels, which can be installed on the roof of building without shadowing other panels, was estimated with various tilt angles.

\subsection{Estimation of Power Generated by FC System Using $\mathrm{H}_{2}$ Produced by Water Electolysis}

In this case study, it is assumed that the surplus power generated by PV system over the electricity demand of households [49] living in the building model would be used for water electrolysis. The Type-S electrolyzer manufactured by IHT [59] whose $\mathrm{H}_{2}$ production rate, power consumption and electrolysis efficiency are $760 \mathrm{Nm}^{3} / \mathrm{h}, 4.45 \mathrm{kWh} / \mathrm{Nm}^{3}$ and $79.5 \%$, is used in this case study. The amount of $\mathrm{H}_{2}$ could be produced by the surplus power generated from PV sys- 
tem is calculated by the following equation:

$$
V_{H_{2}}=\frac{\eta_{e} E_{s}}{P_{e}}
$$

where $V_{H 2}$ is amount of $\mathrm{H}_{2}$ produced $\left(\mathrm{Nm}^{3}\right), E_{s}$ is surplus power generated by $\mathrm{PV}$ system $(\mathrm{kWh}), P_{e}$ is power consumption $\left(\mathrm{kWh} / \mathrm{Nm}^{3}\right), \eta_{e}$ is electrolysis efficiency $(-)$.

It is assumed that the $\mathrm{H}_{2}$ produced by the electolyzer would be used to generate power through a polymer electrolyte fuel cell (PEFC) system. $\mathrm{H}_{2}$ is converted into electricity by FC following the below equation:

$$
\mathrm{H}_{2}+1 / 2 \mathrm{O}_{2}=\mathrm{H}_{2} \mathrm{O}+\eta_{f} Q
$$

where $\eta_{f}$ is power generation efficiency of latest PEFC stationary system based on lower heating value $(=0.39)$ [60], $Q$ is lower heating value of $\mathrm{H}_{2}(=242)$ $(\mathrm{kJ} / \mathrm{mol})$.

In this study, 4 monthly values of the self-sufficiency rate of the proposed combination system consisting of PV and FC was investigated, which are representative of four seasons for Tsu city in Japan. The self-sufficiency rate is defined as the power supplied (from the combined PV and FC system to electricity demand of the building), in this study. The hourly time change in the self-sufficiency rate in the day when the daily mean amount of horizontal solar radiation per month was obtained was estimated.

\section{Results and Discussion}

\subsection{Optimum Installment Procedure of Solar Panel on the Roof of the Building Model}

At first, the optimum tilt angle for installment of solar panel on the roof is investigated using the hourly meteorological data base [57] for several cities in Japan. After that, the instant time change in power generation characteristics of PV system under the optimum tilt angle $\left(a_{\mathrm{t}}\right)$ condition is investigated using the meteorological data base of PV300 including air temperature, solar intensity and wind speed at $10 \mathrm{sec}$ intervals [58]. Compared the power generation characteristics of PV system with the electricity demand data of households in Japan [49], the surplus and deficit between power supply (from PV) and the electricity demand in the building were estimated. The power generation characteristics of FC system using $\mathrm{H}_{2}$ produced by water electrolysis with the surplus power of PV system is investigated to bridge the gap between the power supply and the electricity demand.

To clarify the optimum $a_{\mathrm{t}}$ of solar panel installed on the roof of the building model universally in Japan, this study investigates the daily power energy of PV system averaged per month for five cities in Japan such as Tsu (north latitude: 34 degrees; east longitude: 136 degrees), Fukushima (north latitude: 37 degrees; east longitude: 140 degrees), Tokyo (north latitude: 35 degrees; east longitude: 139 degrees), Sapporo (north latitude: 43 degrees; east longitude: 141 degrees) and Naha (north latitude: 26 degrees; east longitude: 127 degrees) using the hourly 
meteorological data METPV-11 including air temperature, solar intensity and wind speedat 1 hour interval [57]. Tsu is located in the center of Japan. Fukushima is the city which is necessary to be rebuilt overcoming the big earthquake damage. Tokyo is the capital in Japan. Sapporo and Naha are located in the farthest north area and the farthest south area in Japan.

Figures 2-5 show the relationship between daily power energy of PV system averaged per month and $a_{t}$ of solar panel installed on the roof of the building model. In these figures, January, April, July and October are selected as the months which are representative of four seasons in Japan, respectively. In addition, Figure 6 shows the relationship between annual power energy of PV system and $a_{\mathrm{t}}$ of solar panel installed on the roof of the building model for five cities. From these figures, it is revealed that the optimum $a_{t}$ is 0 degree irrespective of city as well as season. Though the optimum $a_{t}$ of solar panel installed on the ground is approximately 20 - 30 degrees in Japan generally [57], the optimum $a_{t}$ of solar panel installed on the roof of the building is 0 degree due to the limitation of the rood area of the building.

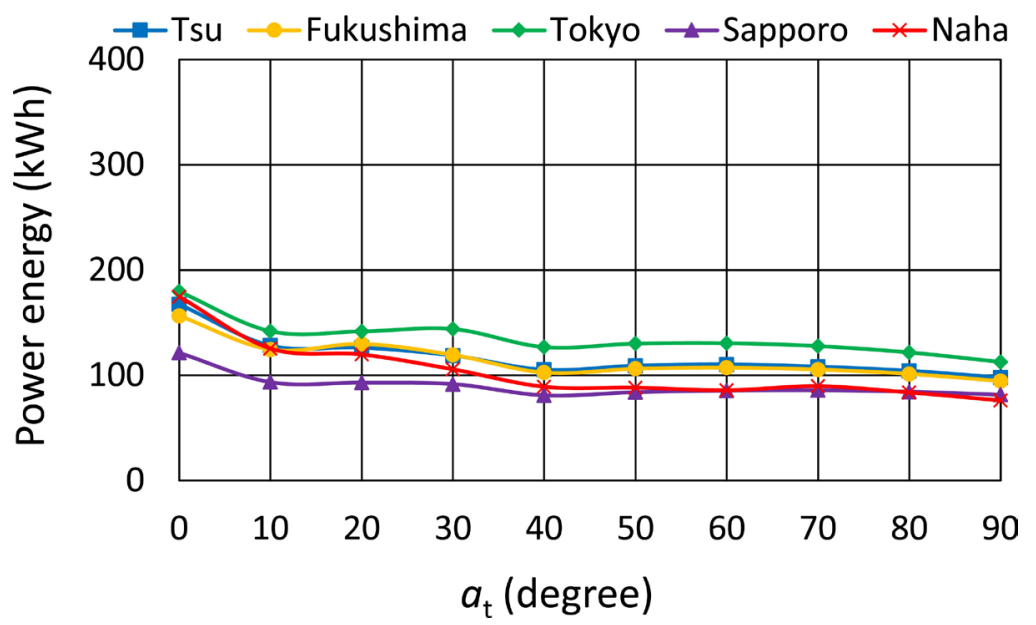

Figure 2. Relationship between daily power energy of PV system averaged per month and tilt angle of solar panel installed on the roof of the building model (January).

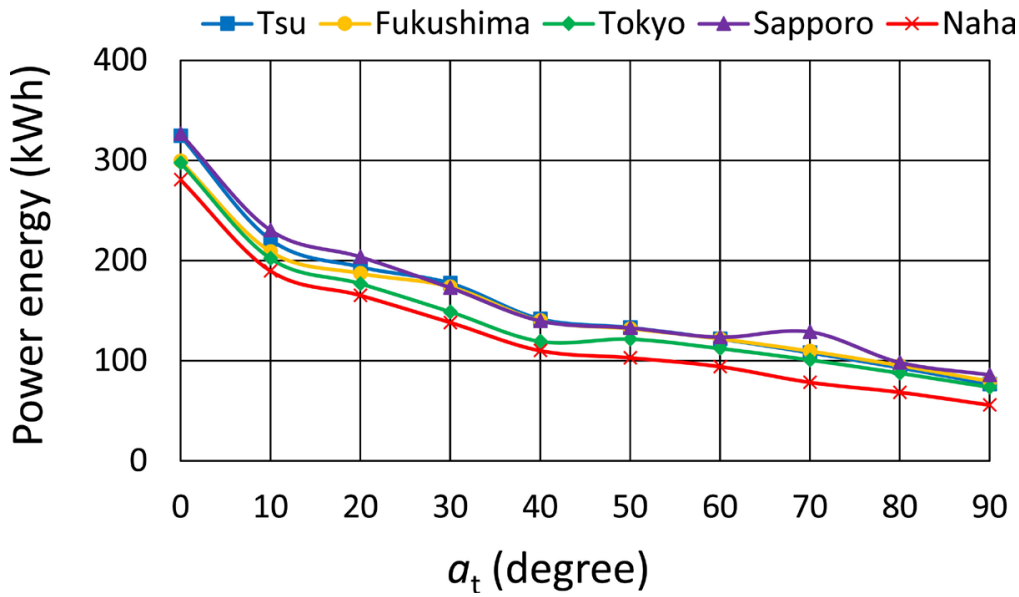

Figure 3. Relationship between daily power energy of PV system averaged per month and tilt angle of solar panel installed on the roof of the building model (April). 


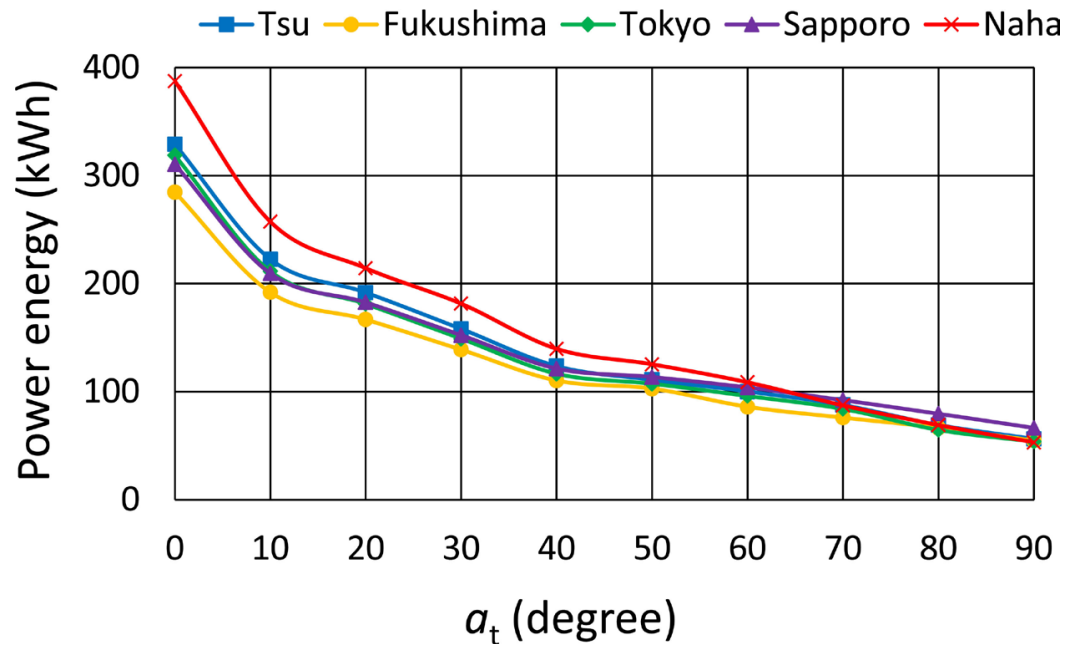

Figure 4. Relationship between daily power energy of PV system averaged per month and tilt angle of solar panel installed on the roof of the building model (July).

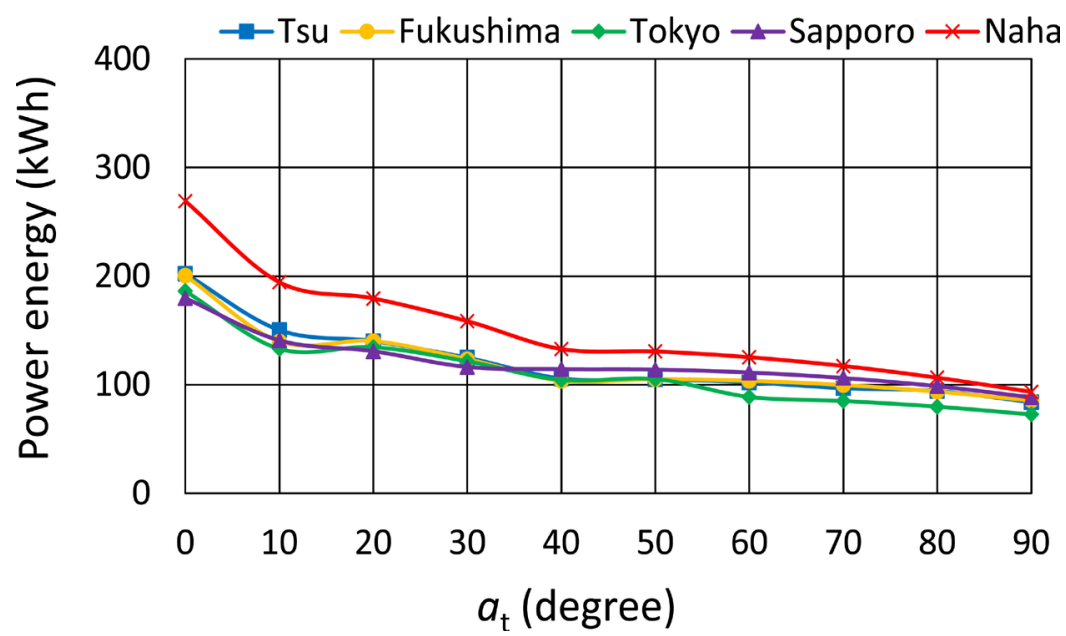

Figure 5. Relationship between daily power energy of PV system averaged per month and tilt angle of solar panel installed on the roof of the building model (October).

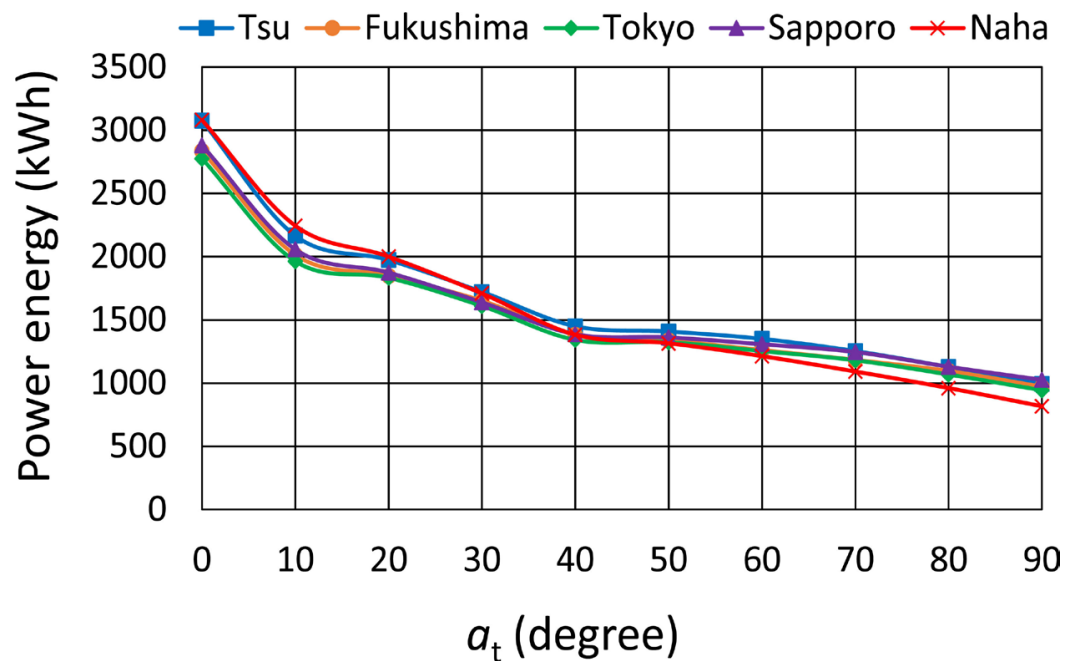

Figure 6. Relationship between annual power energy of PV system and tilt angle of solar panel installed on the roof of the building model. 
Table 2. The number of installable solar panel with consideration of shadow impact.

\begin{tabular}{ccccccccccc}
\hline$a_{\mathrm{t}}$ (degree) & 0 & 10 & 20 & 30 & 40 & 50 & 60 & 70 & 80 & 90 \\
$L(\mathrm{~mm})$ & 0 & 312 & 615 & 898 & 1155 & 1376 & 1555 & 1688 & 1770 & 1796 \\
$N_{\mathrm{s}}(-)$ & 300 & 200 & 175 & 150 & 125 & 125 & 125 & 125 & 125 & 125 \\
$N_{\mathrm{s}} / N(-)$ & 1.00 & 0.67 & 0.58 & 0.50 & 0.42 & 0.42 & 0.42 & 0.42 & 0.42 & 0.42 \\
\hline
\end{tabular}

Table 2 lists the number of installable solar panel on the roof of the building model with consideration of shadow impact. In this table, the relationship between $a_{\mathrm{t}}$ and number of installable solar panel is shown. $N_{\mathrm{s}}$ and $N$ mean the number of installable solar panel with consideration of shadow and that without consideration of shadow, respectively, when $N$ is 300 . From this table, $N_{\mathrm{s}}$ decreases with increase in $a_{t}$. Since the roof area of the building is limited, $N_{\mathrm{s}}$ decreases with increase in $a_{t}$ due to shadow extension. According to the review by this study, there is no report concluding that 0 degree is the optimum $a_{\mathrm{t}}$ for installing solar panel on the roof of the building. Since the effect of shadow and restricted area of roof of building on the power generation performance of PV system is not considered at the same time in the past studies, it is believed that this new finding is obtained. It is thought that the dust impact on the power generation of PV system is afraid when a solar panel is installed at $a_{\mathrm{t}}$ of 0 degree for the roof of the building actually. However, this study suggests cleaning up the dust by water for the case of $a_{t}$ of 0 degree.

\subsection{Evaluation of Characteristics of Power Supply from BIPV and Power Demand in the Building in Tsu City}

Figures 7-10 show hourly power generated from proposed BIPV system and energy demand of 40 households assumed living in the building model in Tsu city in Japan. Hourly power generated by PV system was estimated for the standard day in the month with the mean amount of horizontal solar radiation of the month using the meteorological data base of PV300 [58]. In these figures, January, April, July and October are selected as the months which are representative of four seasons, respectively. The hourly self-sufficiency rate of PV system $\left(R_{\mathrm{PV}}\right)$ is also shown in order to reveal the power supply surplus or deficit in a particular hour.

From Figures 7-10, it is obvious that the generation of PV system increases in the morning up to the noon and decreases after noon to the evening due to solar trajectory, while the electricity demand keeps almost constant during the day and increases from the evening until the midnight. Due to the mismatch between the power generation and electricity demand, $R_{\mathrm{PV}}$ is over $100 \%$ during the daytime and is $0 \%$ during the night-time. Moreover, $R_{\mathrm{PV}}$ during the daytime in April and July are higher than those in January and October. Since the amount of horizontal solar radiation in spring and summer are higher than those in autumn and winter in Japan, the $R_{\mathrm{PV}}$ are higher in April and July than those in January and October. 


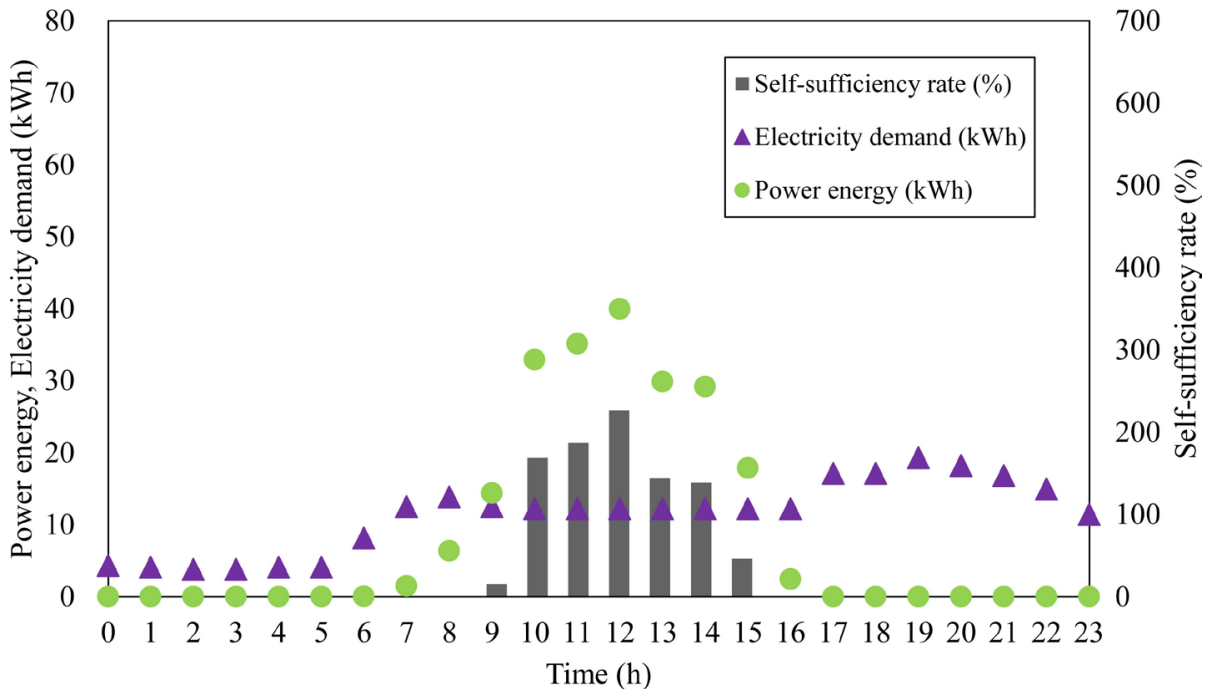

Figure 7. Comparison between hourly power energy of PV system and electricity demand (January).

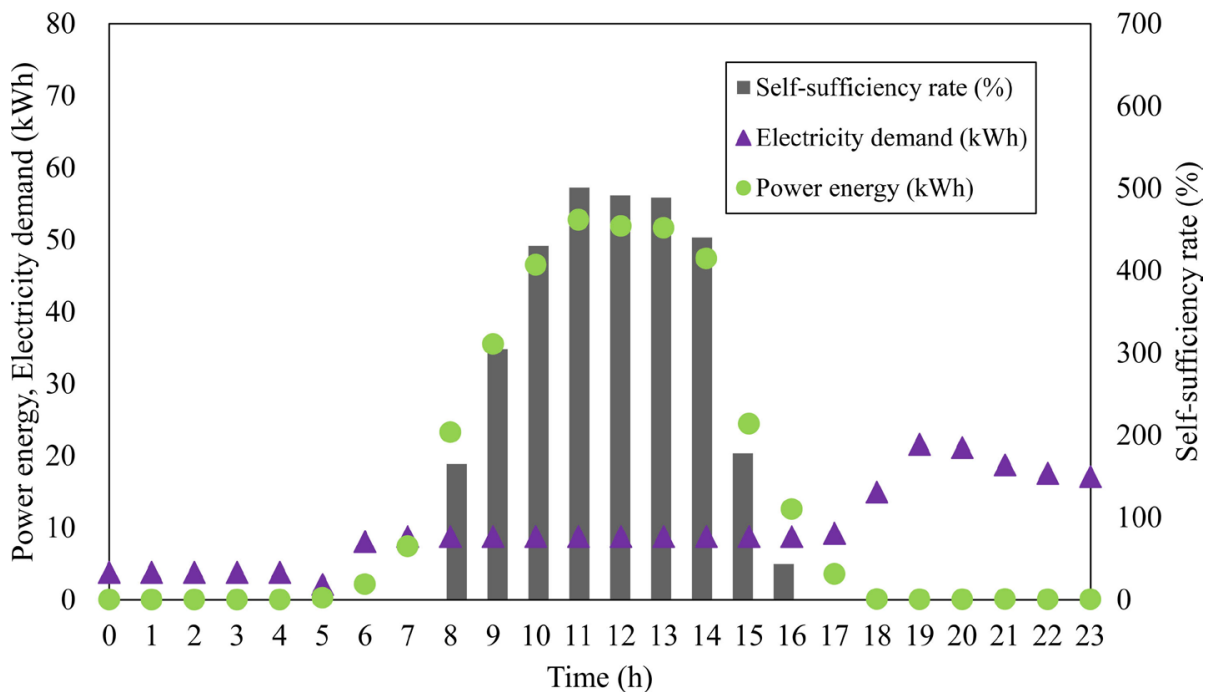

Figure 8. Comparison between hourly power energy of PV system and electricity demand (April).

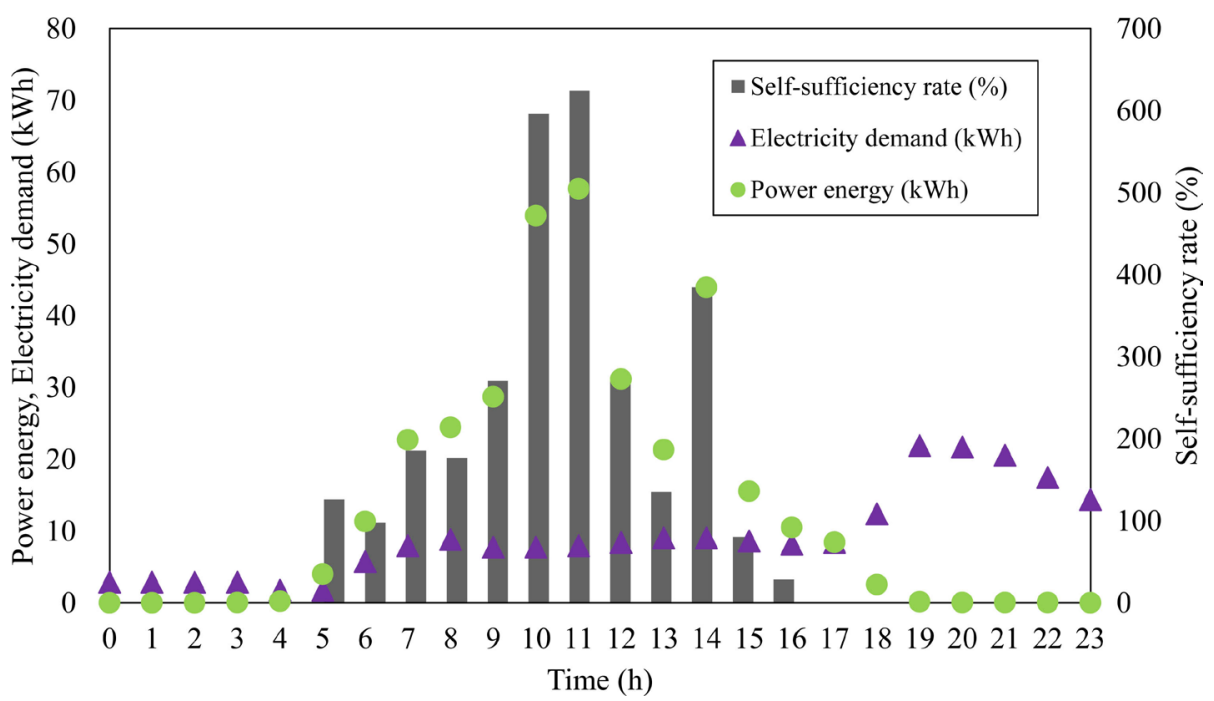

Figure 9. Comparison between hourly power energy of PV system and electricity demand (July). 


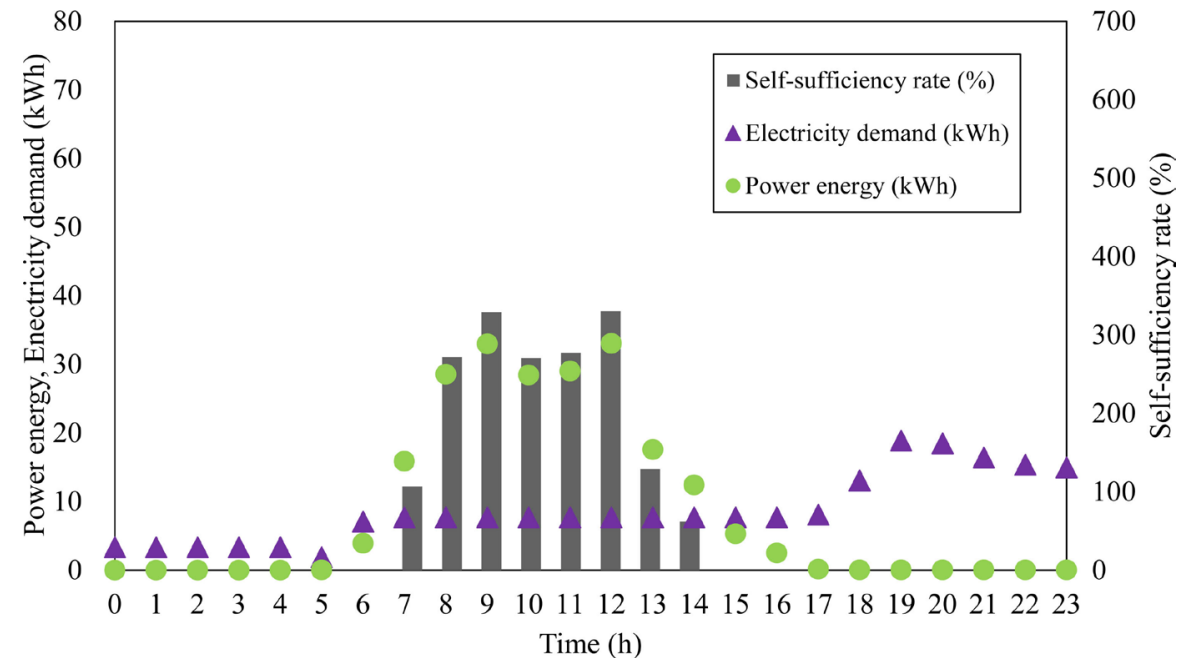

Figure 10. Comparison between hourly power energy of PV system and electricity demand (October).

It was assumed that the surplus electricity generated was used for water electrolysis to produce $\mathrm{H}_{2}$ which is fed into the FC system. The self-sufficiency rate of the FC system $\left(R_{\mathrm{FC}}\right)$ is defined as the ratio of the power generated by FC system to the electricity demand which is not covered by PV system. The average daily $R_{\mathrm{FC}}$ in representative months is calculated and it is given in Table 2 . In this table, $E_{\mathrm{FC}}$ is the power energy of $\mathrm{FC}$ system using $\mathrm{H}_{2}$ generated by water electrolysis with the surplus power of PV system, and $E_{\mathrm{D}}$ is the electricity demand which is not covered by $\mathrm{PV}$ system. In addition, $E_{\mathrm{FC}}, E_{\mathrm{D}}$ and $R_{\mathrm{FC}}$ were calculated as a daily value by summing up the hourly values for the day when the mean amount of horizontal solar radiation was obtained per month in January, April, July and October.

From Table 3, it is known that $R_{\mathrm{FC}}$ is in the range of $15 \%-38 \%$. Since the power energy is high in January and the power energy is low in October, $R_{\mathrm{FC}}$ for these two months are lower. However, it is implied that the power generation of FC system using $\mathrm{H}_{2}$ generated by the surplus power of PV system is effective for bridging the gap between the power supply of PV system and electricity demand of households.

Table 4 shows the change in $R_{\mathrm{FC}}$ in a week which from three days ago to three days after the day when the mean amount of horizontal solar radiation was obtained per month in Tsu city using the meteorological data base of PV300 [58]. It is seen from Table 3 that $R_{\mathrm{FC}}$ changes following the daily meteorological condition. For example, in a cloudy or rainy day when $R_{\mathrm{FC}}$ is $0 \%$, indicating that the surplus power of $\mathrm{PV}$ was not obtained and $R_{\mathrm{FC}}$ can be as high as $49 \%$ in a good sunny day.

As we know that the electricity demand/consumption depends on the number of households in the building, Table 5 and Table 6 give the self-sufficiency rates in a week calculated by the meteorological data base of PV300 [58] and the electricity demand data of households in Japan [49] under the assumptions that there were 20 and 12 households in the building with the same roof areas (i.e. 
Table 3. Self-sufficiency rate of power energy of FC system to the electricity demand which is not covered by PV system.

\begin{tabular}{cccc}
\hline & $E_{\mathrm{FC}}(\mathrm{kWh})$ & $E_{\mathrm{D}}(\mathrm{kWh})$ & $R_{\mathrm{FC}}(\%)$ \\
\hline January & 24 & 186 & 13 \\
April & 56 & 149 & 35 \\
July & 49 & 130 & 38 \\
October & 29 & 138 & 21 \\
\hline
\end{tabular}

Table 4. Change in daily self-sufficiency rate of FC system in a week (40 households in the building).

\begin{tabular}{ccccc}
\hline & January (\%) & April (\%) & July (\%) & October (\%) \\
\hline 3 days ago & 15 & 13 & 41 & 38 \\
2 days ago & 0 & 35 & 18 & 37 \\
1 day ago & 10 & 18 & 12 & 41 \\
Mean solar radiation day & 13 & 35 & 38 & 21 \\
1 day after & 9 & 31 & 19 & 0 \\
2 days after & 15 & 47 & 0 & 33 \\
3 days after & 15 & 49 & 14 & 40 \\
\hline
\end{tabular}

Table 5. Change in daily self-sufficiency rate of FC system in a week (20 households in the building).

\begin{tabular}{ccccc}
\hline & January (\%) & April (\%) & July (\%) & October (\%) \\
\hline 3 days ago & 38 & 28 & 66 & 61 \\
2 days ago & 0 & 64 & 34 & 59 \\
1 day ago & 29 & 38 & 29 & 65 \\
Mean solar radiation day & 33 & 65 & 59 & 35 \\
1 day after & 28 & 56 & 39 & 1 \\
2 days after & 36 & 80 & 6 & 53 \\
3 days after & 38 & 83 & 30 & 63 \\
\hline
\end{tabular}

Table 6. Change in daily self-sufficiency rate of FC system in a week (12 households in the building).

\begin{tabular}{ccccc}
\hline & January (\%) & April (\%) & July (\%) & October (\%) \\
\hline days ago & 46 & 40 & 100 & 93 \\
2 days ago & 1 & 85 & 55 & 90 \\
1 day ago & 36 & 52 & 39 & 56 \\
Mean solar radiation day & 40 & 86 & 98 & 2 \\
1 day after & 33 & 82 & 49 & 81 \\
2 days after & 46 & 114 & 9 & 97 \\
\hline
\end{tabular}


same amount of solar panels installed), respectively.

According to Table 5, it is seen that the $R_{\mathrm{FC}}$ increases compared to Table 4, but still falls below $100 \%$ for each day investigated.

Table 6 shows $R_{\mathrm{FC}}$ in a week in the case of 12 households who live in the building with $12 \mathrm{~m}$ height (=3 stories), when the mean amount of horizontal solar radiation was obtained per month in Tsu city using the meteorological data base of PV300 [58]. It can be seen, in this case, the $R_{\mathrm{FC}}$ over $100 \%$ are obtained in some days in April and high $R_{\mathrm{FC}}$ near $100 \%$ are obtained in some days in July and October. The surplus $\mathrm{H}_{2}$ in the days when $R_{\mathrm{FC}}$ is over $100 \%$ can be stored and used for the days when $R_{\mathrm{FC}}$ is less than $100 \%$. Although Tables 3-6 show the assessment result of one city (Tsu) only, it is expected that the proposed combined PV and FC system has potential to achieve the $100 \%$ self sufficient supply for buildings in Japan, especially in good solar resource areas.

In addition, the proposed systems in different buildings with different energy demands may be connected in future, so the surplus electricity generated from $\mathrm{PV}$ and/or $\mathrm{H}_{2}$ can be transferred between buildings. Moreover, $\mathrm{H}_{2}$ as an energy storage medium has longer term storage efficiency than secondary battery.

\section{Conclusions}

This study has investigated the proper solar panel setting procedure to be installed on the roof of the building. This study proposed a combined PV and FC utilizing $\mathrm{H}_{2}$ produced with surplus power of PV for Japanese buildings. The PV's installation angles and performance of the system have been studied with meteorological data of several cities in Japan. The (energy) self-sufficiency rates of the combination system of PV and FC are also studied with meteorological data for Tsu city in Japan. As a result, the following conclusions have been drawn:

1) The optimum installation angel for solar panel on the roof of the building is 0 degree irrespective of city or season due to the limitation of the roof area of building.

2) Due to the mismatch between the power supply and electricity demand, $R_{\mathrm{PV}}$ is over $100 \%$ during the daytime while it is $0 \%$ during the night-time. $R_{\mathrm{PV}}$ during the daytime in April and July is higher than that in January and October since the amount of horizontal solar radiations in spring and summer are higher than those in autumn and winter in Japan.

3 ) It is revealed that $R_{\mathrm{FC}}$ is in the range of $15 \%-38 \%$ for the day for a big building (i.e., with 40 households).

4) For the smaller buildings with 20 or 12 households, the $R_{\mathrm{FC}}$ over $100 \%$ could be possible in April and high $R_{\mathrm{FC}}$ near $100 \%$ is possible in July and October in the case of 12 households (=3 stories).

\section{References}

[1] Kolhe, M. (2012) Charting a New Energy Future: Research, Development and Demonstration. The electricity Journal, 25, 88-93.

https://doi.org/10.1016/j.tej.2012.01.018 
[2] Larin, P., Paraschivoiu, M. and Aygun, C. (2016) CFD Based Synergistic Analysis of Wind Turbines for Roof Mounted Integration. Journal of Wind Engineering and Industrial Aerodynamics, 156, 1-13. https://doi.org/10.1016/j.jweia.2016.06.007

[3] Heo, Y.G., Choi, N.J., Choi, K.H., Ji, H.S. and Kim, K.C. (2016) CFD Study on Aerodynamic Power Output of a $110 \mathrm{~kW}$ Building Augmented Wind Turbine. Energy and Buildings, 129, 162-173. https://doi.org/10.1016/j.enbuild.2016.08.004

[4] Park, J.H., Chung, M.H. and Park, J.C. (2016) Development of a Small Wind Power System with an Integrated Exhaust Air Duct in High-Rise Residential Buildings. Energy and Buildings, 122, 202-210. https://doi.org/10.1016/j.enbuild.2016.04.037

[5] Yang, A.S., Su, Y.M., Wen, C.Y., Juan, Y.H., Wang, W.S. and Cheng, C.H. (2016) Estimation of Wind Power Generation in Dense Urban Area. Applied Energy, 171, 213-230. https://doi.org/10.1016/j.apenergy.2016.03.007

[6] Li, Q.S., Shu, Z.R. and Chen, F.B. (2016) Performance Assessment of Tall BuildingIntegrated Wind Turbines for Power Generation. Applied Energy, 165, 777-788. https://doi.org/10.1016/j.apenergy.2015.12.114

[7] Park, J., Jung, H.J., Lee, S.W. and Park, J. (2015) A New Building-Integrated Wind Turbine System Utilizing the Building. Energies, 2015, 11846-11870. https://doi.org/10.3390/en81011846

[8] Reda, F., Viot, M., Sipila, K. and Helm, M. (2016) Energy Assessment of Solar Cooling Thermally Driven System Configurations for an Office Building in a Nordic Country. Applied Energy, 166, 27-43. https://doi.org/10.1016/j.apenergy.2015.12.119

[9] Lamnatou, C., Cristofari, C., Chemisana, D. and Canaletti, J.L. (2016) BuildingIntegrated Solar Thermal Based on Vacuum-Tube Technology: Critical Factors Focusing on Life-Cycle Environmental Profile. Renewable and Sustainable Energy Reviews, 65, 1199-1215. https://doi.org/10.1016/j.rser.2016.07.030

[10] Martins, T.A.L., Adolphe, L., Bastos, L.E.G. and Martins, M.A.L. (2016) Sensitivity Analysis of Urban Morphology Factors Regarding Solar Energy Potential of Buildings in a Brazilian Tropical Context. Solar Energy, 137, 11-24. https://doi.org/10.1016/j.solener.2016.07.053

[11] Villarino, J.I., Villarino, A. and Fernandez, F.A. (2017) Experimental and Modeling Analysis of a Building HVAC System Based in a Ground-Coupled Heat Pump and Radiant Floor. Applied Energy, 190, 1020-1028. https://doi.org/10.1016/j.apenergy.2016.12.152

[12] Ogunjuyigbe, A.S.O., Ayodele, T.R. and Akinola, O.A. (2016) Optimal Allocation and Sizing of PV/Wind/Split-Diesel/Battery Hybrid Energy System for Minimizing Life Cost, Carbon Emission and Dump Energy of Remote Residential Building. Applied Energy, 171, 153-171. https://doi.org/10.1016/j.apenergy.2016.03.051

[13] Tong, C.W., Hang, W.X., Hoe, W.K., Mojumder, J.C., Chew, P.S., Huat, S.L. and Hin, L.S. (2016) Performance Assessment of a Hybrid Solar-Wind-Rain Eco-Roof System for Buildings. Energy and Buildings, 127, 1028-1042. https://doi.org/10.1016/j.enbuild.2016.06.065

[14] Ataei, A., Nedaei, M., Rashidi, R. and Yoo, C. (2015) Optimum Design of an OffGrid Hybrid Renewable Energy System for an Office Building. Journal of Renewable and Sustainable Energy, 7, 1-25.

[15] Jones, B.W. and Powell, R. (2015) Evaluation of Distributed Building Thermal Energy Storage in Conjunction with Wind and Solar Electric Power Generation. Renewable Energy, 74, 699-707. https://doi.org/10.1016/j.renene.2014.08.031

[16] Tahani, M., Babayan, N. and Pouyaei, A. (2015) Optimization of PV/Wind/Battery Stand-Alone System, Using Hybrid FPA/SA Algorithm and CFD Simulation, Case Study: Tehran. Energy Conversion and Management, 106, 644-659. 
https://doi.org/10.1016/j.renene.2014.08.031

[17] Lu, Y., Wang, S., Yan, C. and Shan, K. (2015) Impacts of Renewable Energy System Design Inputs on the Performance Robustness of Net Zero Energy Buildings. Energy, 93, 1595-1606. https://doi.org/10.1016/j.energy.2015.10.034

[18] Baljit, S.S.S., Chan, H.Y. and Sopian, K. (2016) Review of Building Integrated Applications of Photovoltaic and Solar Thermal Systems. Journal of Cleaner Production, 137, 677-689. https://doi.org/10.1016/j.jclepro.2016.07.150

[19] Rodriguez, L.R., Lissen, J.M.S., Ramos, J.S., Jara, E.A.R. and Dominguez, S.A. (2016) Analysis of the Economic Feasibility and Reduction of a Building's Energy Consumption and Emissions when Integrating Hybrid Solar Thermal/PV/Micro-CHP Systems. Applied Energy, 165, 828-838.

https://doi.org/10.1016/j.apenergy.2015.12.080

[20] Sotehi, O., Chaker, A. and Maalouf, C. (2016) Hybrid PV/T Water Solar Collector for Net Zero Energy Building and Fresh Water Production: A Theoretical Approach. Desalination, 385, 1-11. https://doi.org/10.1016/j.desal.2016.01.034

[21] Rajoria, C.S., Agrawal, S., Chandra, S., Tiwari, G.N. and Chauhan, D.S. (2016) A Novel Investigation of Building Integrated Photovoltaic Thermal (BiPVT) System: A Comparative Study. Solar Energy, 131, 107-118. https://doi.org/10.1016/j.solener.2016.02.037

[22] Tse, K.K., Chow, T.T. and Su, Y. (2016) Performance Evaluation and Economic Analysis of a Full Scale Water-Based Photovoltaic/Thermal (PV/T) System in an Office Building. Energy and Buildings, 122, 42-52. https://doi.org/10.1016/j.enbuild.2016.04.014

[23] Yang, T. and Athienitis, A.K. (2016) A Review of Research and Developments of Building-Integrated Photovoltaic/Thermal (BIPV/T) Systems. Renewable and Sustainable Energy Reviews, 66, 886-912. https://doi.org/10.1016/j.rser.2016.07.011

[24] Besheer, A.H., Smyth, M., Zacharopoulos, A., Mondo, J. and Pugsley, A. (2016) Review on Recent Approaches for Hybrid PV/T Solar Technology. Energy Research, 40, 2038-2053. https://doi.org/10.1002/er.3567

[25] Rounis, E.D., Athienitis, A.K. and Stathopoulos, T. (2016) Multiple-Inlet Building Integrated Photovoltaic/Thermal System Modeling under Varying Wind and Temperature Conditions. Solar Energy, 139, 157-170. https://doi.org/10.1016/j.solener.2016.09.023

[26] Franco, A. and Fantozzi, F. (2016) Experimental Analysis of a Self Consumption Strategy for Residential Building: The Integration of PV System and Geothermal Heat Pump. Renewable Energy, 86, 1075-1085. https://doi.org/10.1016/j.renene.2015.09.030

[27] Tripathy, M., Sadhu, P.K. and Panda, S.K. (2016) A Critical Review on Building Integrated Photovoltaic Products and Their Applications. Renewable and Sustainable Energy Reviews, 61, 451-465. https://doi.org/10.1016/j.rser.2016.04.008

[28] Jelle, B.P. (2016) Building Integrated Photovoltaics: A Concise Description of the Current State of the Art and Possible Research Pathways. Energies, 9, 21. https://doi.org/10.3390/en9010021

[29] Wikipedia (2017) List of Photovoltaic Installation. https://en.wikipedia.org/wiki/List of rooftop_photovoltaic installations

[30] Ruhang, X. (2016) The Restriction Research for Urban Area Building Integrated Grid-Connected PV Power Generation Potential. Energy, 113, 124-143. https://doi.org/10.1016/j.energy.2016.07.035

[31] Orioli, A. and Gangi, A.D. (2016) Five-Years-Long Effects of the Italian Policies for Photovoltaics on the Energy Demand Coverage of Grid-Connected PV Systems In- 
stalled in Urban Contexts. Energy, 113, 444-460. https://doi.org/10.1016/j.energy.2016.07.059

[32] Humada, A.M., Hojabri, M., Hamada, H.M. and Samsuri, F.B. (2016) Performance Evaluation of Two PV Technologies (c-Si and CIS) for Building Integrated Photovoltaic Based on Tropical Climate Condition: A Case Study in Malaysia. Energy and Buildings, 119, 233-241. https://doi.org/10.1016/j.enbuild.2016.03.052

[33] Davi, G.A., Martin, E.C., Ruther, R. and Solano, J. (2016) Energy Performance Evaluation of a Net Plus-Energy Residential Building with Grid-Connected Photovoltaic System in Brazil. Energy and Buildings, 120, 19-29.

https://doi.org/10.1016/j.enbuild.2016.03.058

[34] Elsayed, M.S. (2016) Optimizing Thermal Performance of Building-Integrated Photovoltaics for Upgrading Informal Urbanization. Energy and Buildings, 116, 232-248. https://doi.org/10.1016/j.enbuild.2016.01.004

[35] Sun, L.L., Li, M., Yuan, Y.P., Cao, X.L., Lei, B. and Yu, N.Y. (2016) Effect Tilt Angle and Connection Mode of PVT Modules on the Energy Efficiency of a Hot Water System for High-Rise Residential Buildings. Renewable Energy, 93, 291-301. https://doi.org/10.1016/j.renene.2016.02.075

[36] Zomer, C., Nobre, A., Reindl, T. and Ruther, R. (2016) Shading Analysis for Rooftop BIPV Embedded in a High-Density Environment: A Case Study in Singapore. Energy and Buildings, 121, 159-164. https://doi.org/10.1016/j.enbuild.2016.04.010

[37] Baumann, L. and Boggasch, E. (2016) Experimental Assessment of Hydrogen Systems and Vanadium-Redox-Flow-Batteries for Increasing the Self-Consumption of Photovoltaic Energy in Buildings. International Journal of Hydrogen Energy, 41, 740-751. https://doi.org/10.1016/j.ijhydene.2015.11.109

[38] Abdin, Z., Webb, C.J. and Gray, E.M. (2015) Solar Hydrogen Hybrid Energy Systems for Off-Grid Electricity Supply: A Critical Review. Renewable and Sustainable Energy Reviews, 52, 1791-1808. https://doi.org/10.1016/j.rser.2015.08.011

[39] Ozgirgin, E., Devrim, Y. and Albostan, A. (2015) Modeling and Simulation of Hybrid Photovoltaic (PV) Module-Electrolyzer-PEM Fuel Cell System for Micro-Cogeneration Applications. International Journal of Hydrogen Energy, 40, 15336-15342. https://doi.org/10.1016/j.ijhydene.2015.06.122

[40] Bensmail, S., Rekioua, D. and Azzi, H. (2015) Study of Hybrid Photovoltaic/Fuel Cell System for Stand-Alone Applications. International Journal of Hydrogen Energy, 40, 13820-13826. https://doi.org/10.1016/j.ijhydene.2015.04.013

[41] Gonzalez, E.L., Llerena, F.I., Perez, M.S., Iglesias, F.R. and Macho, J.G. (2015) Energy Evaluation of a Solar Hydrogen Storage Facility: Comparison with Other Electrical Energy Storage Technologies. International Journal of Hydrogen Energy, 40, 5518-5525. https://doi.org/10.1016/j.ijhydene.2015.01.181

[42] Alnaser, N.W. (2015) Building Integrated Renewable Energy to Achieve Zero Emission in Bahrain. Energy and Buildings, 93, 32-39.

https://doi.org/10.1016/j.enbuild.2015.01.022

[43] Bigdeli, N. (2015) Optimal Management of Hybrid PV/Fuel Cell/Battery Power System: A Comparison of Optimal Hybrid Approaches. Renewable and Sustainable Energy Reviews, 42, 377-393. https://doi.org/10.1016/j.rser.2014.10.032

[44] Torreglosa, J.P., Garcia, P., Fernandez, L.M. and Jurado, F. (2015) Energy Dispatching Based on Predictive Controller of an Off-Grid Wind Turbine/Photovoltaic/Hydrogen/Battery Hybrid System. Renewable Energy, 74, 326336. https://doi.org/10.1016/j.renene.2014.08.010

[45] Cano, A., Jurado, F., Sanchez, H. and Fernandez, L.M. (2014) Optimal Sizing of Stand-Alone Hybrid Based on PV/WT/FC by Using Several Methodologies. Journal of Energy Institute, 87, 330-340. https://doi.org/10.1016/j.joei.2014.03.028 
[46] Ghahnavieh, A.R. and Nowdeh, S.A. (2014) Optimal PV-FC Hybrid System Operation Considering Reliability. Electrical Power and Energy Systems, 60, 325-333. https://doi.org/10.1016/j.ijepes.2014.03.043

[47] 47Rekioua, D., Bensmail, S. and Bettar, N. (2014) Development of Hybrid Photovoltaic-Fuel Cell System for Stand-Alone Application. International Journal of Hydrogen Energy, 39, 1604-1611. https://doi.org/10.1016/j.ijhydene.2013.03.040

[48] Sehar, F., Pipattanasomporn, M. and Rahman, S. (2016) An Energy Management Model to Study Energy and Peak Power Savings from PV and Storage in Demand Responsive Buildings. Applied Energy, 173, 406-417. https://doi.org/10.1016/j.apenergy.2016.04.039

[49] The Society of Heating, Air-Conditioning and Sanitary of Engineering of Japan (1998) Assessment, Plan and Design of Co-Generation System by City Gas. Maruzen, Tokyo.

[50] Nishimura, A., Ito, T., Kakita, M., Murata, J., Ando, T., Kamada, Y., Hirota, M. and Kolhe, M. (2014) Impact of Building Layout on Wind Turbine Power Output in the Built Environment: A Case Study of Tsu City. Journal of the Japan Institute of Energy, 84, 315-322. https://doi.org/10.3775/jie.93.315

[51] Ministry of Internal Affairs and Communications (2017) Dwelling by Area of Floor Space (6 Groups) a Tenure of Dwelling (2 Groups)-Japan, 3 Major Metropolitan Areas, Prefectures and Major Cities (1998-2008).

[52] New Energy and Industrial Technology Development Organization of Japan (2017) Guideline on Field Test Project of Photovoltaic Power Generation for Design, Construction and System. http://www.nedo.go.jp/content/100110086.pdf

[53] Panasonic (2017) Products Lineup. http://sumai/panasonic.jp/solar/lineup.html

[54] Panasonic (2017) Power Conditioner with High Conversion Efficiency. https://sumai.panasonic.jp/solar/need power conditioners.html

[55] Kawamoto, K., Nakatani, S., Hagihara, R. and Nakai, T. (2002) High Efficiency HIT Solar Cell. Sanyo Technical Review, 34, 111-117.

[56] Oozeki, T., Izawa, T., Otani, K., Tsuzuki, K., Koike, H. and Kurokawa, K. (2005) An Evaluation Method for PV Systems by Using Limited Data Item. IEEJ Transaction on Power Energy, 125, 1299-1307. https://doi.org/10.1541/ieejpes.125.1299

[57] New Energy and Industrial Technology Development Organization of Japan (2017) METPV-11. http://www.nedo.go.jp/library/nissharyou.html?from=b

[58] Chubu Electric Power (2014) The Irradiance Data of the Project "PV300" (Electric Data Base).

[59] IHT (2017) Technical Information/Benefits of IHT's Electrolysers. http://www.iht.ch/technologie/electrolysis/industry/technical-information-benefitselectrolysers.html

[60] Panasonic (2017) Specification of ENEFARM. https://panasonic.co.jp/ap/FC/about 01.html 
Submit or recommend next manuscript to SCIRP and we will provide best service for you:

Accepting pre-submission inquiries through Email, Facebook, LinkedIn, Twitter, etc. A wide selection of journals (inclusive of 9 subjects, more than 200 journals)

Providing 24-hour high-quality service

User-friendly online submission system

Fair and swift peer-review system

Efficient typesetting and proofreading procedure

Display of the result of downloads and visits, as well as the number of cited articles Maximum dissemination of your research work

Submit your manuscript at: http://papersubmission.scirp.org/

Or contact sgre@scirp.org 